philosophy' was ill-founded and false, the book is an interesting and sympathetic study of Spencer's work and personality. A serious blemish in Spencer's evolution theory seemed to Mr. Elliot to be the assumption of the transmission by heredity of acquired characters, an assumption which he took to be without justification. $\mathrm{He}$ had already argued to the same effect in the introduction he wrote to his translation of Lamarck's" Philosophie Zoologique". This translation, which was done with great skill and accuracy, appeared in 1914.

Mr. Elliot had a rooted contempt for what he called 'metaphysics', which he stigmatised as "a maze of sesquipedalian verbiage, beyond the reach of science to defend or to refute". Probably he got his conception of 'metaphysics' from the treatment in "First Principles" of "the Unknowable', which he regarded as altogether extraneous and unnecessary to Spencer's philosophy as a whole. He himself defended a thorough-going doctrine of materialism, according to which 'physical law' is universally dominant, and mind or consciousness is "only an inert accompaniment of material cerebral changes". In his later volume, "Modern Science and Materialism ", which was published in 1919, he was, however, compelled to modify to some extent his earlier view.

Mr. Elliot was a forcible and trenchant writer; his books and essays were always readable, even when they failed to carry conviction. He was happier in expounding scientific theories than in criticising philosophical ones; and his articles on social and political topics were characterised by keen insight and sagacity. His materialistic doctrine is already a spent force; but his survey of Spencer's system and his account of Lamarck's contributions to biology are not likely soon to be forgotten.

G. Dawes Hicks.

\section{Dr. P. A. Wagner.}

The death of Percy Albert Wagner on Nov. 11, 1929 , at the early age of forty-four years, removed from a larger sphere than that of South Africa one of the most prominent workers on the economic side of geology. Conjointly, the South African School of Mines, Freiberg and Heidelberg, contributed to the determining of his career. Much was accomplished in that relatively short life, principally among the platinum and diamond deposits of the Transvaal, and to a rather less extent in the geology and mineral resources of South-West Africa, for Dr. Wagner seldom strayed in his investigations beyond the southern section of the continent. His Memoirs on the "Fides-Stavoren Tinfields" (1921), on the "Iron Deposits of the Union of South Africa", (1928), and that exceptionally interesting work on "The Pretoria Salt-pan, a Soda Caldera" (1922), are typical examples of the thorough-and also the clear and systematic-manner in which the subject on hand was treated.

The salt-pan formed one of the 'Problems' dealt with in Wagner's presidential address to the Geological Society of South Africa in 1917. An earlier book on "The Diamond Fields of South Africa", written in 1915 (preceded in 1909 by a volume on the same subject published in Berlin), is still a standard work of reference. "The Platinum Deposits and Mines of South Africa ", in which the structure and petrography of the Bushveld Complex receive all but exhaustive treatment, is an outstanding example of the minute care with which he handled his subject, dealing with it, so far as was possible, from every point of view. In describing these sulphide ores, he was in his element.

Appointed Geologist for the Mineral Survey in 1918, Wagner left Government service in 1927 to undertake consulting work, chiefly concerned with platinum and diamonds, finding it necessary to crowd much writing into time which most men would have considered fully occupied with strictly professional matters. In his last memoir for the Geological Survey, that on the "Iron Deposits", he laments that he had only two and a half months for the microscopic work and systematising and summarising the observations of the preceding ten years. "The Platinum Deposits" was written hurriedly, but one looks in vain in either for those "obvious shortcomings" he saw himself in the earlier work. The memoir on "The Geology and Mineral Industry of South-West Africa "(1916) is a most useful compendium of original observations and the publications of other geologists, mostly German, but perhaps the broad outlines of stratigraphical geology were not altogether Wagner's métier, though one feels that had his bent led him in this direction, he would have accomplished much.

As his field work was essentially South African, so Dr. Wagner's publications are principally to be found in South African journals. No paper of his appears under the ægis of the Geological Society of London or in the Transactions of the Institution of Mining and Metallurgy. This is of small moment; his reputation was world-wide, and even those of his profession who had never met him felt a keen sense of loss at his untimely death. J. P.

We regret to announce the following deaths :

Prof. John N. Cobb, dean of the College of Fisheries at the University of Washington, Seattle, a past president of the Pacific Fisheries Society, on Jan. 13, aged sixty-two years.

Mr. G. C. Dudgeon, C.B.E., formerly consulting agriculturist, Ministry of Agriculture, Egypt, well known for his interest in tropical agriculture and entomology, on May 4, aged sixty-two years.

Prof. Stephen A. Forbes, since 1917 chief of the Illinois State Natural History Survey, member of the U.S. National Academy of Sciences and past president of the American Entomological Society and of the Association of Economic Entomologists, on Mar. 13, aged eighty-five years.

Dr. Christine Ladd-Franklin, lecturer in psychology and logic at Columbia University, and originator of the theory of colour vision known by her name, on Mar. 5, aged eighty-two years.

Prof. Max Matthes, director of the University Medical Clinic, Königsberg, one of the secretaries of the German Society for Natural Science and Medicine for the forthcoming meeting in Konigsberg, on Mar. 26, aged sixty-five years.

No. 3160, VoL. 125] 